\title{
Therapeutic management of Buxtonella sulcata infection in Surti buffalo Calves
}

\author{
D.B. Bhoi*, J.K. Raval, G.M. Pandya and M.A. Katariya \\ Livestock Research Station, Navsari Agricultural University, Navsari - 396450, Gujarat (INDIA) \\ *Corresponding author: E-mail: drdhirenvet@ gmail.com Mob: +919925253536 \\ Journal of Livestock Science (ISSN online 2277-6214) 12: 276-278 \\ Received on 13/7/21; Accepted on 27/8/21; Published on 15/9/21 \\ doi. 10.33259/JLivestSci.2021.276-278
}

\begin{abstract}
The present study describes the clinical signs, diagnosis via microscopic faecal examination and treatment of Buxtonella sulcata infection in 26 Surti buffalo calves. The study was aimed to control diarrhea caused by Buxtonella sulcata. Buxtonella sulcata infection or buxtonellosis is an important pathogenic factor for causing diarrhoea in suckling and post-weaning calves. Buxtonella sulcata infection is found more frequently associated with other parasitic infections that cause diarrhea. It is also described by inanition, rough body coat and lacrimation apart from generalized weakness and diarrhoea. All the calves were successfully treated with parenteral medicinal therapy using antiprotozoal, antiinflammatory and anti-histaminics for five days.
\end{abstract}

Keywords: Buxtonella sulcate; calves; diarrhea; Surti buffaloes 


\section{Introduction}

Surti buffalo is a native buffalo breed from Gujarat state of India. It is found in Vadodara, Panchmahal, Mahisagar, Anand, Surat, Bharuch, Narmada, Tapi, Navsari, Valsad and Dangs districts of South Gujarat. Parasitic diseases are one of the major problems in livestock, and are caused by bad managemental and climatic conditions, frequent exposure to parasites and lack of knowledge of livestock owners about the transmission of parasites.

Parasitic diarrheal disease continues to be a major cause of morbidity and mortality in the developing world. Neonatal and young calves are highly susceptible to enteric infections by various pathogens, including bacteria, viruses, fungi, protozoa, and helminthes (Julia et al., 2014). The most commonly identified parasitic agents responsible for diarrhea are Cryptosporidium spp., Eimeria spp., Giardia spp., Toxocara vitulorum and Buxtonella sulcate (Tomczuk et al., 2005). However, bacterial, viral, fungal agents and nutritional factors also play a role in causing diarrhea. Endoparasitic infection in domestic ruminants causes significant economic losses to the farmers and hence is a disease of major concern. Different intestinal protozoa (Cryptosporidium, Giardia, Eimeria) are responsible for causing diarrhea and even death in neonatal and young bovine calves (Urquhart et al., 2003). One of these protozoons is Buxtonella sulcata which may be a probable causative agent of diarrhea which has unknown etiology in cattle and considered as an opportunistic ciliate protozoan inhabitating colon of bovines. It was first reported and named by Jameson (1926) from caecum of the cattle. Morphologically, it is similar to Balantidium coli, inhabitates in gastrointestinal tracts of ruminants (Jameson, 1926). Increased number of this protozoan parasite in alimentary canal of the infected animal may result in diarrhoea and poor condition of the animal (Kumar et al., 2017). The main clinical sign of Buxtonella sulcata infection in bovines is debilitating diarrhoea that sometimes may cause death in the untreated animals (Ganai et al., 2015). The current study was conducted to evaluate the clinical signs, diagnosis and successful therapeutic management of Buxtonella sulcata infection in 26 Surti buffalo calves.

\section{History and Clinical signs}

A total of 26 Surti buffalo calves below 12 months of age were reported to Veterinary Dispensary, Livestock Research Station, Navsari Agricultural University, Navsari, between July 2020 and October 2020 with a complaint of offensive-odor diarrhoea since last 3-4 days and progressive debility. All the calves were suffered from offensive-odor diarrhea with arched-back position, pale yellow mucous membranes and significant weight loss with no fever. Gross faecal examination revealed greenish watery faeces along with some mucus inmixed with it. Out of total 26 calves 8 calves were moderately and 1 calf was extremely debilitated. All the affected calves were dull and depressed with rough and muddy body coat and partial loss of appetite was noticed. All the calves were kept in a muddy paddock since the season of study was rainy where highest rainfall of the state was noticed in South Gujarat.

\section{Diagnosis and Treatment}

Fecal examination was carried out to record the presence of cysts or trophozoites of Buxtonella sulcata. Confirmatory diagnosis was based on the microscopic faecal examination under the 40X magnification. Microscopic examination revealed presence of cyst with clear wall, kidney shaped macronucleus and round micronucleus and ciliated trophozoite with two openings in posterior end of Buxtonella sulcata (Fig. 1 \& 2).

The mean values of some physiological parameters like rectal temperature, heart rate, respiration rate, body weight gain and some haematological parameters of all the calves were within the normal range (Table 1).

Table 1: Physiological and haematological parameters of the affected Surti buffalo calves

\begin{tabular}{|l|l|l|l|}
\hline Sr.No. & Parameter & Average Value & $\begin{array}{l}\text { Normal Range } \\
\text { (Radostits } \text { et al., 2000) }\end{array}$ \\
\hline 1 & Rectal Temperature $\left({ }^{0} \mathrm{~F}\right)$ & $101.2 \pm 0.07$ & $101-102$ \\
\hline 2 & Ave. body weight $<3$ months $(\mathrm{kg})$ & $41.15 \pm 1.96$ & -- \\
\hline 3 & Ave. body weight 3-6 months $(\mathrm{kg})$ & $73.15 \pm 2.75$ & -- \\
\hline 4 & Ave. body weight $>6$ months $(\mathrm{kg})$ & $112.21 \pm 2.88$ & -- \\
\hline 5 & Respiration rate / minute & $28 \pm 0.03$ & $12-16$ \\
\hline 6 & Heart rate / minute & $79 \pm 1.32$ & $40-60$ \\
\hline 7 & Haemoglobin $(\mathrm{g} / \mathrm{dl})$ & $12.6 \pm 0.25$ & $8.5-15$ \\
\hline 8 & Red Blood Cell count $($ million/mm3 $)$ & $8.48 \pm 0.17$ & $5-10$ \\
\hline 9 & White blood cells $($ cells/ $\mu$ l) & $11517 \pm 195$ & $4000-12000$ \\
\hline 10 & Packed cell volume $($ Haematocrit $)(\%)$ & $32.16 \pm 0.71$ & $24-46$ \\
\hline 11 & Mean corpuscular volume (fl/cell) & $35.60 \pm 0.90$ & $20-40$ \\
\hline
\end{tabular}

All the 26 calves were treated using oxytetracycline (inj. Steclin, Cadila Healthcare Ltd.) @ 10mg / kg body weight / day; flunixin meglumine (inj. Fluxivet, Carus Laboratories Pvt. Ltd., Karnal, Haryana) @ 2.2 mg / kg body 
weight and chlorpheniramine maleate (inj. Anistamin, Intas Pharmacueticals, Ahmedabad, Gujarat) @ $0.5 \mathrm{mg} / \mathrm{kg}$ body weight for five consecutive days to treat them. Oxytetracycline antibiotic was preferred for the present study because it has also proven broad spectrum antiprotozoal properties.

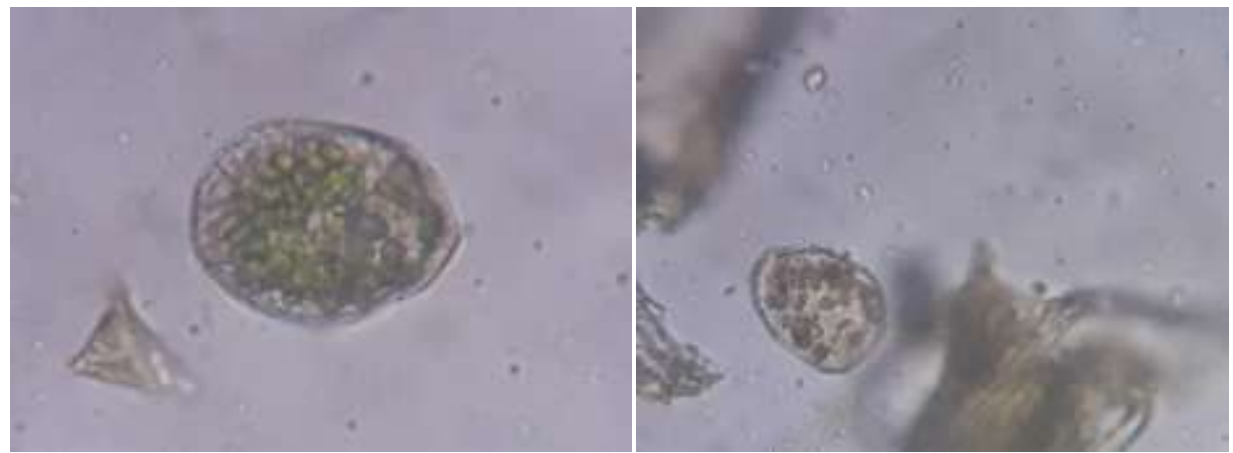

Fig 1\&2: Microscopic field showing cyst of Buxtonella sulcata (with clear wall, kidney shaped macronucleus and round micronucleus and ciliated with two openings in posterior end) under $40 \mathrm{X}$

\section{Results and Discussion}

The affected calves showed uneventful improvement from the next day post-treatment. Post-therapeutic remission of clinical symptoms confirmed complete recovery. The faecal sample of all the calves for confirmation were again examined on $6^{\text {th }}$ and $15^{\text {th }}$ day post treatment and found negative for Buxtonella sulcata cysts and trophozoites. The effected calves were successfully treated with parenteral medicinal therapy using oxytetracycline, flunixin meglumine and chlorpheniramine maleate. Oxytetracycline is a broad spectrum antibacterial and antiprotozoal drug which is active against Buxtonella sulcata (Hasheminasab et al., 2015). The present study was conducted during the rainy season where there is more possibility of Buxtonella sulcata infection in calves. The muddy floor and extreme environmental stress might be the predisposing factors for the occurrence of the Buxtonella sulcata infection. These findings are in accordance with Hasheminasab et al. (2015) and Maharana et al. (2016) who also found more susceptibility of calves to be infected with Buxtonella sulcata. Among all parasitic infections, Buxtonella sulcata $(14.57 \%)$ was reported to be the most prevalent gastrointestinal protozoa in bovines with higher proportion in all age groups, seasons, sex and breeds (Maharana et al., 2016). Buxtonella sulcata was considered to be non-pathogenic protozoa, but recent studies reported and admitted its pathogenicity associated with diarrhoea (Al-Saffar et al., 2010 and Maharana et al., 2016) which is supported by present study also. Buxtonella sulcata infection generally causes minor health problems especially in young ruminants but it significantly affects the growth and productivity causing remarkable economic losses to the farmers. Hence, Frequent and scheduled herd screening via microscopic faecal examination is advised in the prevalent areas of Buxtonella sulcata infections for better growth and productivity in animals.

\section{References}

1) Al-Saffar, T.M., Suliman, E.G., Al-Bakri, H.S. (2010). Prevalence of intestinal ciliate Buxtonella sulcata in cattle in Mosul. Iraqi Journal of Veterinary Sciences, 24 (1):27-30.

2) Ganai, A., Parveen, S., Kaur, D., Katoch, R., Yadav, A., Godara, R. (2015). Incidence of Buxtonella sulcata in bovines in R.S. Pura, Jammu. Journal of Parasitological Diseases, 39 (3):446-7.

3) Hasheminasab, S.S., Darbandi, M.S., Talvar, H.M., Maghsood, H., Khalili, S. (2015). Chemotherapy of Buxtonella sulcata in cattle in Sanandj, Iran. International Journal of Medicine, 3 (2):118-119.

4) Jameson, P.A. (1926). A ciliate, Buxtonella sulcata, from the caecum of the cattle. Parasitology, 18 (2): 182-186.

5) Julia, G., David, R., Kurt, P. and Miriam, C.S. (2014). Giardiosis and other enteropathogenic infections: A study on diarrhoeic calves in Southern Germany. B.M.C. Research Notes, 7: 112.

6) Kumar, B., Maharana, B.R., Prashad, A., Joseph, J.P., Patel, B.R. (2017). Incidence of buxtonella sulcata in Jaffrabadi buffaloes of south-western Gujarat, India. Buffalo Bulletin, 36 (4):623-8.

7) Maharana, B.R., Kumar, B., Sudhakar, N.R., Behera, S.K., Patbandha, T.K. (2016). Prevalence of gastrointestinal parasites in bovines in and around Junagadh (Gujarat). Journal of Parasitological Diseases, 40 (4):1174-1178.

8) Radostits, O.M., Gay, C.C., Blood, D.C. and Hinchcliff, K.W. (2000) Veterinary Medicine, 9th edn W.B. Saunders, London, pp. $1819-1822$.

9) Tomczuk, K., Kurek, B., Stec, A., Studzinska, M. and Mochol, J. (2005). Incidence and clinical aspects of colon ciliates Buxtonella sulcata infection in cattle. Bulletin of Veterinary Inst. Pulawy, 49: 29-33.

10) Urquhart, G.M., Armour, J., Duncan, J.L., Dunn, A.M. and Jennings, F.W. (2003). Veterinary Parasitology. 2nd ed. Blackwell Science LTD, Osney Mead 276. PP 209-250. 